\title{
KEMAMPUAN EKSTRAK SENYAWA AKTIF BAKTERI ENDOFIT DALAM MENGHAMBAT PERTUMBUHAN Fusarium oxysporum f.sp. PADA KELAPA SAWIT
}

\section{Ability of Active Compound Extract of Endophytic Bacteria to Inhibit the Growth of Fusarium oxysporum f.sp. in Oil Palm}

\author{
Emilia Candrawati ${ }^{1}$, Bedah Rupaedah ${ }^{2, *}$, Sumpono $^{1}$, Agus Sundaryono $^{1}$ \\ ${ }^{1}$ Prodi Pascasarjana Pendidikan IPA, FKIP, Universitas Bengkulu, Kandang Limun, Bengkulu \\ ${ }^{2}$ Balai Bioteknologi, Badan Pengkajian dan Penerapan Teknologi, Gedung 630 Kawasan Puspiptek \\ Serpong, Tangerang Selatan 15346, Banten \\ *Email: bedah.rupaedah@bppt.go.id
}

\begin{abstract}
Wilt vessels disease in oil palm plants is caused by Fusarium oxysporum f.sp. This disease is very harmful because of its ability to kill the infected oil palm plant in less than a year. Endophytic bacteria are likely to be biological controllers for the disease because of their ability to produce bioactive antifungal compounds. Isolation of endophytic bacteria from oil palm plant and activity test of their active compounds against $\mathrm{F}$. oxysporum $f . s p$. in vitro had been done. Antagonistic test of endophytic bacterial isolates against $\mathrm{F}$. oxysporum f.sp. was carried out using a double culture method. The potential endophytic bacterial isolates were extracted using ethyl acetate solvent for their active compounds, which were then tested for its activity in inhibiting the growth of $\mathrm{F}$. oxysporum f.sp. The results showed that the active compound extract of B11 endophytic bacteria with the incubation time of 24 and 54 hours gave the growth inhibition of F. oxysporum f.sp. at the level of $29.23 \%$ and $43.85 \%$, respectively.
\end{abstract}

Keywords: antagonistic test, bioactive compound, endophytic bacteria, F. oxysporum f.sp., oil palm

\begin{abstract}
ABSTRAK
Penyakit layu pembuluh pada tanaman kelapa sawit disebabkan oleh Fusarium oxysporum f.sp. Penyakit ini menjadi penyebab kematian tanaman kelapa sawit yang telah terinfeksi dalam waktu kurang dari setahun. Bakteri endofit asal tanaman kelapa sawit dimungkinkan menjadi pengendali hayati bagi penyakit ini karena kemampuan bakteri tersebut memproduksi senyawa bioaktif yang bersifat antifungi. Isolasi bakteri endofit dari tanaman kelapa sawit dan uji aktivitas senyawa aktifnya terhadap $F$. oxysporum f.sp. secara in vitro telah dilakukan. Uji antagonis isolat bakteri endofit terhadap jamur patogen $F$. oxysporum f.sp. menggunakan metode kultur ganda. Isolat bakteri endofit potensial diekstrak senyawa aktifnya dengan menggunakan pelarut etil asetat, kemudian senyawa aktif ini diuji aktivitasnya dalam menghambat pertumbuhan jamur patogen F. oxysporum f.sp. Hasil penelitian menunjukkan bahwa ekstrak senyawa aktif bakteri endofit B11 dengan waktu inkubasi 24 dan 54 jam memberikan daya hambat terhadap $F$. oxysporum f.sp. sebesar masing-masing $29,23 \%$ dan $43,85 \%$.
\end{abstract}

Kata Kunci: bakteri endofit, F. oxysporum f.sp., kelapa sawit, senyawa aktif, uji antagonis 


\section{PENDAHULUAN}

Kelapa sawit (Elaeis guineensis Jacq.) merupakan salah satu komoditas ekspor di Indonesia. Tercatat, pada September 2016, Indonesia mampu mengekspor 24,15 juta ton Crude Palm Oil (CPO) yang setara dengan USD 14,744 juta (Ditjenbun 2013).

Kelapa sawit tidak memerlukan pemeliharaan yang khusus, namun demikian beberapa serangan hama penyakit dapat menyebabkan menurunnya produktivitas tanaman tersebut. Penyakit yang sering menyerang kelapa sawit adalah penyakit layu yang disebabkan oleh jamur Fusarium oxysporum f.sp. Jamur Fusarium dianggap sangat merugikan karena dapat menginfeksi tanaman (Ngittu et al. 2014). Jamur ini menyerang semua bagian dari tanaman kelapa sawit dengan ciri adanya layu pada daun kelapa sawit. Infeksi oleh jamur ini seringkali dimulai dengan menyerang akar dan batang tanaman, sedangkan serangan pada daun dan buah bersumber dari percikan air atau peralatan yang sudah terkontaminasi.

Penyakit layu fusarium pada kelapa sawit memang sangat sulit dikendalikan. Hal ini karena jamur $F$. oxysporum f.sp. memiliki struktur bertahan berupa klamidospora. Struktur ini dapat bertahan dalam tanah sebagai saprofit dalam waktu relatif lama walau tanpa tanaman inang (Sastrahidayat 2017). Jamur F. oxysporum f.sp. juga dapat menyerang tanaman pada semua stadia (Alfizar et al. 2011). Selain itu menurut Hadisutrisno (2005), sulitnya pengendalian penyakit ini disebabkan karena penularannya melalui tanaman yang sudah terinfeksi, sehingga penyebarannya menjadi cepat dan meluas.

Pengendalian penyakit layu Fusarium yang paling banyak dilakukan oleh petani adalah dengan penggunaan fungisida. Akan tetapi, cara ini dianggap kurang efektif sebab tidak dapat mematikan jamur patogen tersebut secara keseluruhan. Selain itu, penggunaan fungisida dalam dosis tinggi dengan jangka waktu yang lama juga dapat menyebabkan kerusakan ekosistem tanah dan resistensi mikroba patogen. Oleh karena itu, penggunaan fungisida dianggap bukan solusi yang tepat dalam mengendalikan penyakit layu Fusarium. Pengendalian penyakit layu Fusarium akan lebih baik dilakukan dengan meningkatkan kesehatan tanaman kelapa sawit (Bivi et al. 2016). Salah satunya adalah pencegahan dengan inokulasi bibit penyakit pada tanaman muda sehingga dapat mengurangi penyakit di persemaian dan tanaman muda di lapangan (Widanengsih 2015). Pencegahan dengan cara inokulasi bibit penyakit hanya dapat mengurangi serangan penyakit, namun tidak dapat mengendalikan jamur patogen $F$. oxysporum f.sp. yang sudah menyerang tanaman kelapa sawit secara keseluruhan. Penggunaan agen antagonis disinyalir dapat menghambat perkembangan patogen (Alabouvette et al. 2006). Agen antagonis juga mempunyai efek lain terhadap tanaman, antara lain dengan meningkatkan ketahanan tanaman (Ahemad dan Kibret 2014).

Bakteri endofit dapat digunakan sebagai agen antagonis terhadap jamur patogen $F$. oxysporum f.sp. yang menyerang tanaman kelapa sawit. Bakteri endofit dilaporkan efektif dalam mengendalikan penyakit pada berbagai jenis tanaman dari rumput-rumputan hingga tanaman berkayu (Hushiarian et al. 2013). Bakteri endofit mampu memberikan ketahanan bagi tanaman inang karena mikroba ini mampu memproduksi senyawa metabolit sekunder yang dapat menghambat laju pertumbuhan jamur patogen (Mufidah et al. 2013). Margino (2008) telah melakukan penelitian mengenai kemampuan antibiotik senyawa metabolit sekunder yang diisolasi dari fungi endofit. Hasil penelitian tersebut menunjukkan bahwa 4 isolat memiliki daya hambat tertinggi, yakni berturut-turut 5,5 terhadap B.subtilis, 5,6 terhadap $F$. oxysporum, 3,5 terhadap C. albicans, dan isolat NGK-1 yang memiliki daya hambat terhadap $B$. subtilis $(5,2)$ dan $F$. oxysporum $(2,3)$. Berdasarkan penelitian ini, besar peluang senyawa metabolit sekunder dari bakteri endofit kelapa sawit untuk memiliki daya hambat yang tinggi terhadap mikroba patogen, terutama sebagai antifungi $F$. oxysporum f.sp.

Penelitian ini bertujuan untuk mengetahui aktivitas bakteri endofit kelapa sawit yang dapat digunakan sebagai pengendali hayati dalam menghambat pertumbuhan jamur patogen $F$. oxysporum f.sp. secara in vitro. 


\section{BAHAN DAN METODE}

\section{Bahan penelitian}

Bahan yang digunakan dalam penelitian ini antara lain jaringan tanaman kelapa sawit yang terinfeksi $F$. oxysporum $s p$., kultur murni $F$. oxysporum sp. yang diperoleh dari hasil isolasi dan koleksi isolat Balai Bioteknologi-BPPT, Nutrient Agar (NA), Nutrient Broth (NB), Potato Dextrose Agar (PDA), silika gel, aquades, etanol $70 \%$, $\mathrm{NaClO} 5,25 \%$, etil asetat, sodium sulfat anhidrat dan n-heksan.

\section{Isolasi bakteri endofit}

Bakteri endofit diisolasi dari akar tanaman kelapa sawit terinfeksi $F$. oxysporum sp. Akar dipilih sebagai sumber bakteri endofit karena bakteri endofit banyak ditemukan di sekitar akar dibandingkan di bagian tanaman lainnya (Kaaria et al. 2012). Isolasi bakteri endofit diawali dengan mencuci akar dengan air mengalir guna menghilangkan tanah dan kotoran yang menempel. Akar selanjutnya dipotongpotong dengan ukuran $\pm 2 \mathrm{~cm}^{2}$, sampel dikering-anginkan di atas cawan petri. Sampel dimasukkan ke dalam gelas Erlenmeyer $250 \mathrm{~mL}$, dan ditambahkan etanol $70 \%$ sampai terendam, dikocok pelan dan disterilisasi selama 2 menit. Cairan etanol $70 \%$ dibuang, sterilisasi dilanjutkan dengan bayclean ( $\mathrm{NaClO} 5,25 \%$ ) selama 2 menit, dibilas dengan akuades steril sebanyak 3 kali, masing-masing selama 1 menit. Sterilisasi dilakukan secara aseptis di dalam LAF kabinet. Bahan-bahan tersebut ditiriskan di dalam cawan petri steril, dipotong-potong dengan pisau skalpel steril menjadi ukuran $\pm 1 \mathrm{~cm}^{2}$. Bagian-bagian tersebut ditanam di dalam medium NA di dalam cawan petri steril serta diinkubasi pada suhu kamar $\left(28^{\circ} \mathrm{C}\right)$ selama 24 jam.

\section{Seleksi dan pemurnian isolat}

Bakteri endofit dalam penelitian ini diseleksi berdasarkan morfologi bakteri seperti koloni dominan, perbedaan bentuk dan warna koloni (Maithili et al. 2014). Medium yang digunakan untuk pemurnian bakteri endofit adalah medium NA. Satu ose bakteri endofit diinokulasikan ke medium NA dengan metode streak atau zig-zag kemudian diinkubasi selama 24 jam dalam suhu $28,3^{\circ} \mathrm{C}$.

\section{Pembuatan kurva pertumbuhan bakteri}

Kurva pertumbuhan diperlukan untuk menentukan waktu inkubasi optimum bagi bakteri endofit yang diisolasi dari tanaman kelapa sawit terinfeksi $F$. oxysporum f.sp. Kurva pertumbuhan dalam penelitian ini dibuat dengan menghitung jumlah sel bakteri selama inkubasi pada interval waktu tertentu. Penghitungan jumlah sel bakteri untuk membuat kurva pertumbuhan diawali dengan membuat prekultur, yakni 1 ose bakteri endofit ditumbuhkan dalam media aktivasi NB sebanyak $30 \mathrm{~mL}$, diinkubasi menggunakan shaker incubator selama 24 jam dengan suhu $28,3^{\circ} \mathrm{C}$ pada $150 \mathrm{rpm}$. Setelah kultur berumur 24 jam, kultur diambil sebanyak $1 \mathrm{~mL}$ dan dipindahkan ke dalam media NB sebanyak $30 \mathrm{~mL}$ dalam tabung Erlenmeyer $100 \mathrm{~mL}$ dan diinkubasi kembali pada suhu $28,3^{\circ} \mathrm{C}$ dengan kecepatan agitasi $150 \mathrm{rpm}$ dengan variasi waktu $6,12,24,30,36,48,54,60,72$ jam. Sebanyak $1 \mathrm{~mL}$ kultur dipindahkan ke dalam tabung reaksi yang berisi $9 \mathrm{~mL}$ aquades. Selanjutnya dilakukan pengenceran hingga $10^{-6}$. Setelah diencerkan, sampel kemudian diukur jumlah sel bakterinya dengan menggunakan haemacytometer dibawah mikroskop dengan pembesaran 100× (Ihsan 2013). Kurva pertumbuhan akan didapat dari nilai konversi jumlah sel bakteri hasil perhitungan dengan haemacytometer.

\section{Uji antagonis}

Bakteri endofit yang berpotensi sebagai agen hayati diuji daya hambatnya terhadap jamur patogen $F$. oxysporum f.sp. dengan metode kultur ganda (Fokhema et al. dalam Budi dan Hadie 2015). Uji antagonis diawali dengan menumbuhkan kultur jamur F. oxysporum f.sp. pada media PDA dengan jarak $2 \mathrm{~cm}$ dari tepi cawan petri. Pada media yang sama, diletakkan paper dish dengan diameter $6 \mathrm{~mm}$ dengan jarak $4 \mathrm{~cm}$ dari koloni jamur $F$. oxysporum f.sp. Sebanyak $100 \mu \mathrm{L}$ kultur bakteri endofit diteteskan pada paper dish. Sampel selanjutnya diinkubasi selama 15 hari pada suhu $28,3^{\circ} \mathrm{C}$. Satu cawan petri yang telah diinokulasikan jamur $F$. oxysporum f.sp. tetapi tidak diberi perlakuan dengan kultur bakteri dibuat sebagai kontrol.

Penghambatan pertumbuhan miselium jamur $F$. oxysporum f.sp. oleh bakteri endofit 
dihitung berdasarkan rumus yang diadaptasikan dari rumus yang dikemukakan oleh Fokhema (1973) dalam Skidmore (1976) yaitu:

$$
I=\frac{\left(r_{1}-r_{2}\right)}{\left(r_{1}\right)} \times 100 \%
$$

Keterangan :

$\mathrm{I}=$ persentase penghambatan

$r_{1}=$ jari-jari koloni jamur $F$. oxysporum $s p$. yang merupakan kontrol negatif

$r_{2}=$ jari-jari koloni jamur $F$. oxysporum $s p$. yang tumbuh ke arah bakteri endofit

Perhitungan persentase hambatan dilakukan pada data hasil pengukuran jarijari koloni jamur $F$. oxysporum sp. pada hari kelima belas setelah inokulasi bakteri endofit.

\section{Ekstraksi senyawa aktif}

Bakteri yang memiliki daya hambat terbesar (potensial) akan diekstraksi senyawa aktifnya. Ekstraksi tersebut didasarkan pada waktu inkubasi bakteri memasuki pertengahan fase eksponensial dan fase stasioner.

Isolat aktif dibuat prekulturnya pada labu Erlenmeyer $100 \mathrm{~mL}$ yang mengandung NB berisi bakteri endofit kurang lebih $50 \mathrm{~mL}$. Medium cair diinkubasi selama 24 jam dalam shaker incubator pada suhu $28,3^{\circ} \mathrm{C}$ dan agitasi $150 \mathrm{rpm}$. Setelah 24 jam, sebanyak 1 $\mathrm{mL}$ bakteri diambil dari prekultur dan ditambahkan NB sebanyak $50 \mathrm{~mL}$ ke dalam Erlenmeyer kemudian difermentasikan pada shaker incubator. Sel dipisahkan dengan sentrifugasi pada kecepatan $6.000 \mathrm{rpm}$ selama 15 menit untuk memisahkan endapan dan supernatan. Supernatan dipindahkan ke dalam botol dan diekstraksi dengan etil asetat (EtOAc) sebanyak 3 kali untuk mendapatkan ekstrak senyawa aktif dengan menggunakan shaker resipro dengan agitasi 150 rpm (Ahamed 2012 dalam Ihsan 2013). Ekstrak senyawa aktif dievaporasi dengan vakum evaporator pada suhu $40^{\circ} \mathrm{C}$ hingga didapat ekstrak pekat dari larutan tersebut (Garcia et al. 2012). Ekstrak pekat kemudian dikering-anginkan di dalam lemari asam. Ekstrak kering yang diperoleh ditimbang untuk dilakukan pengujian aktivitas senyawa aktif terhadap pertumbuhan F. oxysporum f.sp.

\section{Pengujian aktivitas ekstrak senyawa aktif}

Pengujian ini digunakan untuk senyawa aktif total (crude extract) dengan menggunakan metode difusi agar atau metode cakram. Sebelum pengujian, ekstrak kering senyawa aktif dilarutkan dengan metanol pada konsentrasi 10.000 ppm. Koloni jamur $F$. oxysporum f.sp. diinokulasikan pada media PDA dengan jarak $2 \mathrm{~cm}$ dari tepi cawan petri. Paper dish steril diameter $6 \mathrm{~mm}$ diletakkan pada media yang sama dengan jarak $4 \mathrm{~cm}$ dari tepi koloni jamur F. oxysporum f.sp, ditetesi ekstrak senyawa aktif sebanyak $20 \mu \mathrm{L}$. Cawan petri selanjutnya dimasukkan ke dalam lemari pendingin selama 1,5 jam pada suhu $4^{\circ} \mathrm{C}$. Cawan petri yang berisi koloni jamur $F$. oxysporum f.sp. dan ekstrak senyawa aktif diinkubasi selama 15 hari pada suhu $28,3^{\circ} \mathrm{C}$.

Pengamatan dilakukan dengan mengukur pertumbuhan jamur $F$. oxysporum f.sp. dan diameter zona hambat yang terbentuk serta membandingkan dengan pertumbuhan jamur $F$. oxysporum f.sp. pada kontrol yang tidak diperlakukan dengan senyawa aktif (Kaaria et al. 2012).

\section{HASIL DAN PEMBAHASAN}

Isolasi bakteri endofit dari akar tanaman kelapa sawit yang terinfeksi jamur patogen F. oxysporum f.sp. menghasilkan 11 isolat dengan ukuran, bentuk, dan warna koloni yang berbeda-beda. Hasil uji antagonis 11 isolat bakteri endofit tersebut terhadap pertumbuhan jamur patogen $F$. oxysporum f.sp. menunjukkan bahwa isolat bakteri B1, B4, dan B11 memberikan daya hambat yang signifikan, sedangkan 8 isolat bakteri lain tidak memberikan daya hambat yang signifikan.

Persentase penghambatan terhadap jamur patogen $F$. oxysporum f.sp. tertinggi diberikan oleh $\mathrm{B} 1$ sebesar $74,55 \%$ dan isolat B11 sebesar $63,64 \%$, sedangkan isolat B4 memberikan penghambatan sebesar $54,55 \%$ (Gambar 1). Adanya persentase penghambatan lebih dari 50 persen menunjukkan bahwa isolat B1, B4, dan B11 memiliki senyawa aktif yang mampu menghambat pertumbuhan jamur $F$. oxysporum f.sp. Adanya penghambatan dapat dilihat dengan terbentuknya zona bening di sekitar inokulum bakteri endofit. 


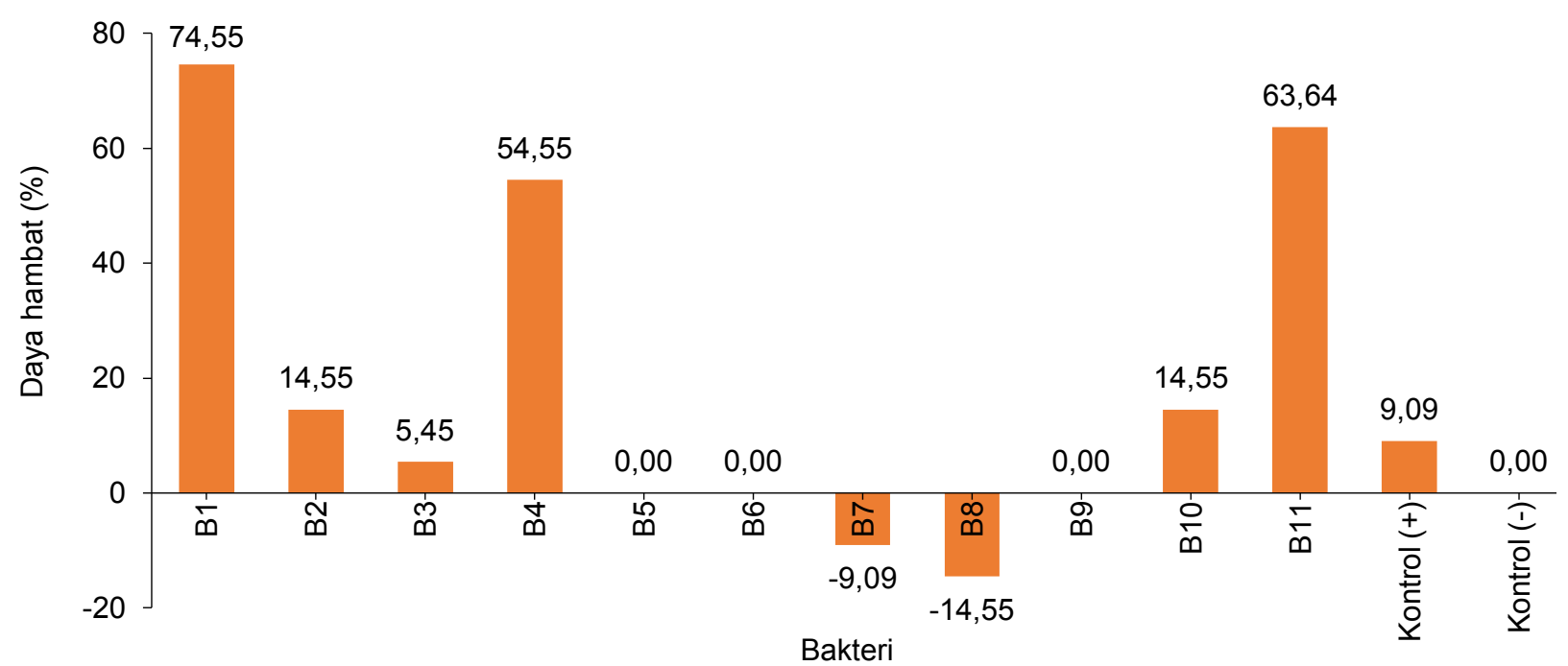

Gambar 1. Persentase penghambatan bakteri endofit terhadap F. oxysporum f.sp.

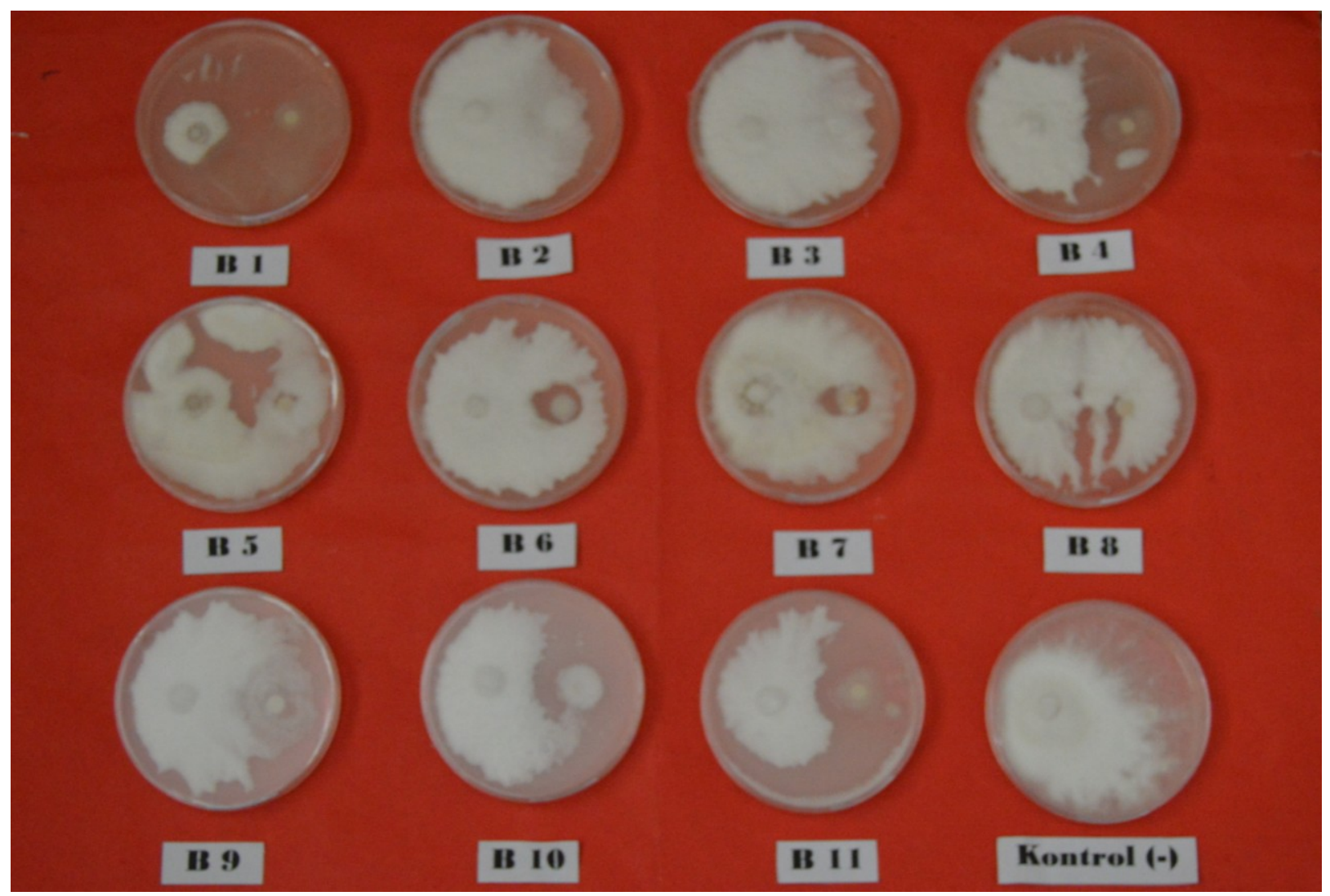

Gambar 2. Hasil uji antagonis isolat bakteri endofit terhadap F. oxysporum f.sp.

Pada kontrol positif berupa nystatin 10.000 ppm tidak terbentuk zona bening.

Isolat B1 selain dapat menghambat pertumbuhan jamur $F$. oxysporum f.sp., ternyata juga dapat mengakibatkan nekrosis pada jamur tersebut. Hal ini terlihat dari luas permukaan jamur $F$. oxysporum f.sp. yang makin lama makin terkikis habis (Gambar 2).

Ketiga bakteri endofit yang memiliki kemampuan menghambat jamur $F$. oxysporum f.sp. diisolasi senyawa aktifnya berdasarkan kurva pertumbuhan dengan variasi waktu dimulainya fase eksponensial hingga fase stasioner (Gambar 3). Kurva pertumbuhan bakteri terdiri dari fase lag, fase log (eksponensial) dan fase stasioner. Setiap fase tersebut akan memengaruhi produk metabolisme yang dihasilkan. Produk 


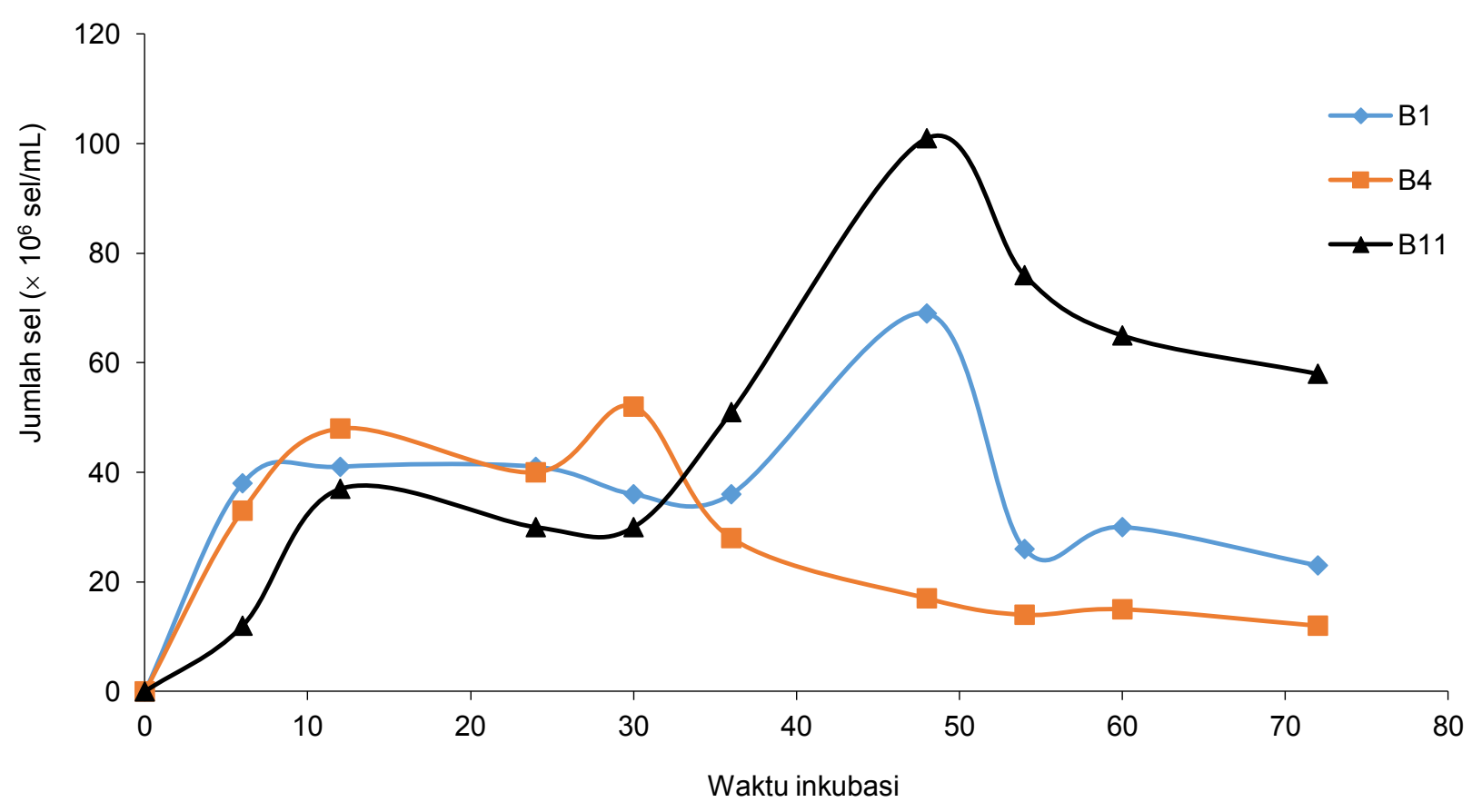

Gambar 3. Kurva pertumbuhan bakteri endofit B1, B4, dan B11

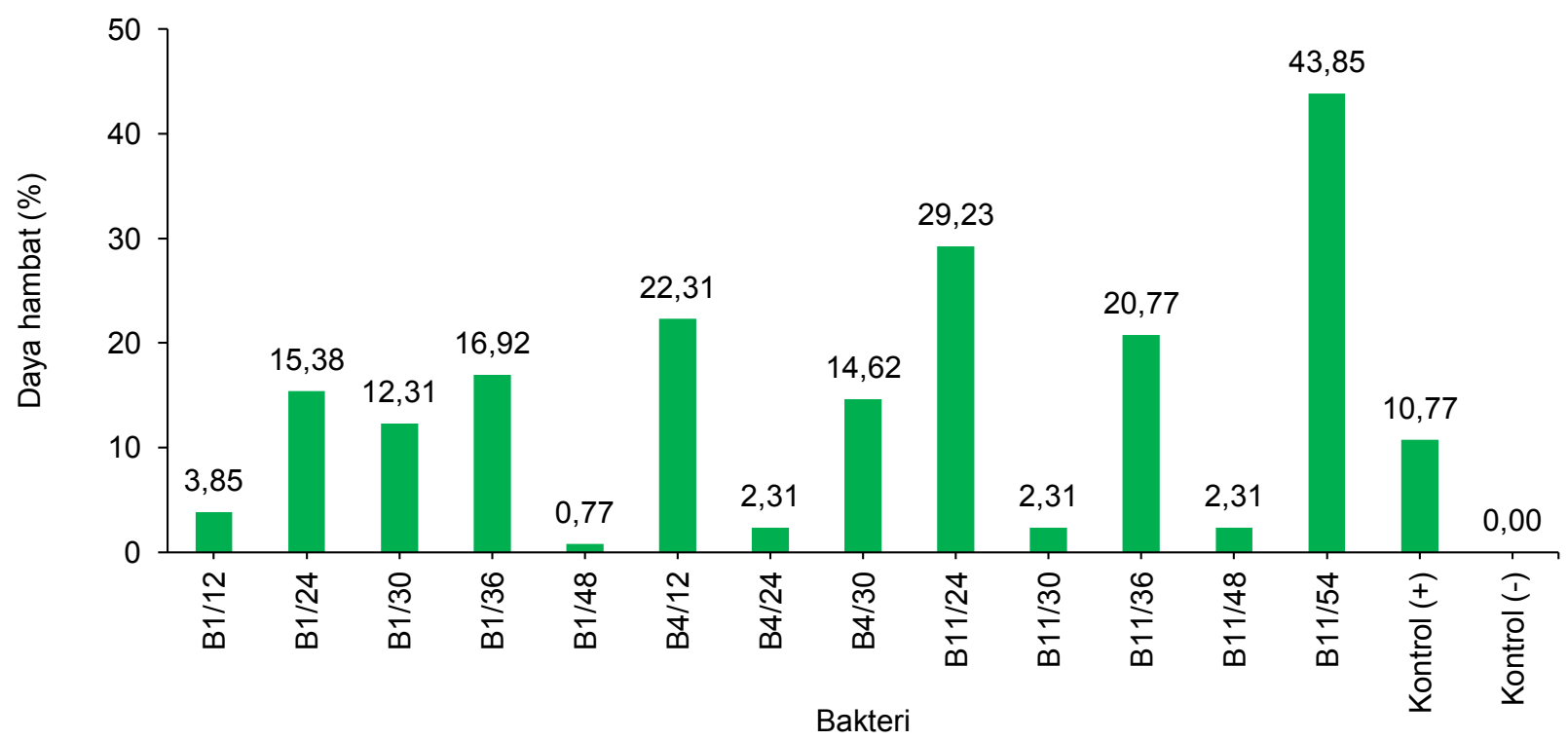

Gambar 4. Persentase penghambatan ekstrak senyawa aktif yang diekstraksi dari bakteri B1, B4, dan B11 berdasarkan waktu inkubasi terhadap F. oxysporum f.sp.

metabolit primer dihasilkan pada fase eksponensial, sedangkan metabolit sekunder dihasilkan pada fase stationer (Stanbury et al. 2016).

Berdasarkan hasil uji ekstrak senyawa aktif bakteri endofit (Gambar 4), persentase penghambatan terbesar ditunjukkan oleh ekstrak senyawa aktif bakteri B11 dengan waktu inkubasi 54 jam dengan rata-rata persentase penghambatan sebesar $43,85 \%$. Bakteri B11 mengalami fase stationer pada jam ke-48 dan mulai mengalami lisis pada jam ke-54. Bakteri endofit mulai memproduksi senyawa aktif setelah memasuki fase stationer. Xie et al. (2009) dalam Budianto dan Suprastyani (2017) menyatakan bahwa aktivitas bakteri dapat dideteksi pada pertumbuhan pertengahan fase eksponensial dan cepat mencapai maksimum pada fase awal stationer. Akan tetapi dalam penelitian ini, aktivitas senyawa aktifnya justru maksimum pada awal fase 
lisis. Bakteri endofit mengalami fase lisis setelah melewati fase stationer. Metabolit sekunder yang diproduksi pada fase stationer dianggap mengganggu pertumbuhan bakteri, akan tetapi metabolit sekunder ini dimungkinkan aktif terhadap jamur patogen F. oxysporum f.sp. Oleh karena itu, hasil uji ekstrak senyawa aktifnya justru memberikan penghambatan lebih besar pada sampel bakteri B11 yang diinkubasi selama 54 jam.

Bakteri B11 mengalami dua kali fase stationer. Puncak pertumbuhan bakteri B11 pertama kali terjadi pada jam ke-12, namun pertumbuhannya statis di jam ke-24 hingga jam ke-30. Waktu inkubasi yang menunjukkan pertumbuhan bakteri statis merupakan fase stationer. Pada fase inilah bakteri akan memproduksi senyawa metabolit sekundernya. Oleh karena itu, hasil uji ekstrak senyawa aktif bakteri B11 yang diinkubasi selama 24 jam juga memberikan daya hambat terhadap $F$. oxysporum f.sp. dengan persentase sebesar $29,23 \%$. Hasil uji senyawa aktif yang diekstrak dari bakteri endofit B1 dan B4 diketahui tidak memberikan daya hambat yang signifikan terhadap jamur $F$. oxysporum f.sp.

\section{KESIMPULAN}

Uji antagonis isolat bakteri endofit menunjukkan penghambatan terbesar diberikan oleh isolat B1 sebesar $74,55 \%$, isolat B11 sebesar $63,64 \%$, serta isolat B4 sebesar $54,55 \%$. Hasil uji ekstrak senyawa aktifnya menunjukkan hanya bakteri B11 yang memberikan aktivitas antifungi terhadap F. oxysporum f.sp. Ekstrak senyawa aktif bakteri endofit B11 dengan waktu inkubasi 54 jam memberikan daya hambat sebesar $43,85 \%$, sedangkan ekstrak senyawa aktif bakteri B11 dengan waktu inkubasi 24 jam sebesar $29,23 \%$. Dari hasil tersebut dapat disimpulkan bakteri endofit B11 baik agen hayatinya maupun ekstrak senyawa aktifnya berpotensi untuk dikembangkan sebagai bahan aktif biokontrol untuk jamur patogen $F$. oxysporum f.sp yang menyerang tanaman kelapa sawit.

\section{UCAPAN TERIMAKASIH}

Penulis mengucapkan terimakasih kepada Balai Bioteknologi, BPPT yang telah memfasilitasi penelitian ini, PT. Bioteknologi Nusantara atas izin pengambilan sampel berupa tanah, akar, dan daun tanaman kelapa sawit yang terinfeksi $F$. oxysporum f.sp., dan seluruh pihak yang telah membantu.

\section{DAFTAR PUSTAKA}

Ahemad M and Kibret M (2014) Mechanisms and applications of plant growth promoting rhizobacteria: Current perspective. J King Saud University Science 26:1-20. doi: 10.1016/j.jksus.2013.05.001

Alabouvette C, Olivain C, Steinberg C (2006) Biological control of plant disease: the European situation. Eur J Plant Pathol 114:329-341. doi: 10.1007/s10658005-0233-0

Alfizar A, Marlina M, Hasanah N (2011) Upaya pengendalian penyakit layu Fusarium oxysporum dengan pemanfaatan agen hayati cendawan FMA dan Trichoderma harzianum. J Floratek 6:8-17. doi: 10.24815/floratek.v6i1.494

Bivi MSHR, Paiko AS, Khairulmazmi A, Akhtar MS, Idris AS (2016) Control of basal stem rot disease in oil palm by supplementation of calcium, copper, and salicylic acid. Plant Pathol $J$ 32:396-406 doi: 10.5423/PPJ.OA.03.2016.0052

Budianto B, Suprastyani H (2017) Aktivitas antagonis Bacillus subtilis terhadap Streptococcus iniae dan Pseudomonas fluorescens. J Veteriner 18:409-415. doi: 10.19087/jveteriner.2017.18.3.409

Budi IS, Hadie J (2015) Pengendalian penyakit kelapa sawit fase pre-nursery dengan konsorsium mikroba endofit dari lahan basah. Prosiding Seminar Nasional dan Kongres Perhimpunan Fitopatologi Indonesia, 11-13 November 2015, Bekasi

Ditjenbun (2013) Pertumbuhan areal kelapa sawit meningkat. Berita Utama. www.ditjenbun.pertanian.go.id.

Direktorat Jenderal Perkebunan Kementerian Pertanian. Diakses 10 Juli 2018

Garcia A, Rhoden SA, Bernardi WJ, Orlandelli RC, Azevedo JL, Pamphile JA (2012) Antimicrobial activity of 
crude extracts of endophytic fungi isolated from medicinal plants Sapindus saponaria L. J Appl Pharm Sci 2:35-40. doi: 10.7324/JAPS.2012.21007

Hadisutrisno B (2005) Budidaya Vanili Tahan Penyakit Busuk Batang. ISBN: 9794894850. Penebar Swadaya, Depok

Hushiarian R, Yusof NA, Dutse SW (2013) Detection and control of Ganoderma boninense: strategies and perspectives. SpringerPlus 2:555. doi: 10.1186/2193-1801-2-555

Insan F (2013) Identifikasi metabolit sekunder potensial antibakteri pada bakteri endorizosfer Ageratum conyzoides. Skripsi, Universitas Pendidikan Indonesia

Kaaria P, Matiru V, Ndungu M (2012) Antimicrobial activities of secondary metabolites produced by endophytic bacteria from selected indigenous Kenyan plants. Afr $\mathrm{J}$ Microbiol Res 6:7253-7258. doi: 10.5897/AJMR12.785

Ngittu YS, Mantiri FR, Tallei TE, Kandou FEF (2014) Identifikasi genus jamur Fusarium yang menginfeksi eceng gondok (Eichhornia crassipes) di Danau Tondano. J Ilmiah Pharmacon 3:156-161

Maithili SS, Senthamil M, Ramanathan G (2014) Isolation of secondary metabolite from seawater bacterial population and screening of their bioactive potential against urinary tract pathogens sourced from HIV infected patients. Int J Curr Microbiol Appl Sci 3:540-548

Margino S (2008) Produksi metabolit sekunder (antibiotik) oleh isolat jamur endofit Indonesia. Majalah Farm Indones 19:86-94

Mufidah, Rante $\mathrm{H}$, Rahim A, Agustina R, Pakki E, Talbani A (2013) Aktivitas antifungi metabolit sekunder fungii endofit yang diisolasi dari Mezzetia parviflora Becc. Majalah Farmasi dan Farmakologi 17:69-72

Sastrahidayat IR (2017) Penyakit Tumbuhan yang disebabkan oleh Jamur. UB Press, Malang

Skidmore AM (1976) Intraction in relation to biological control of plant pathogens. pp 507-528. In Dickinson $\mathrm{CH}$ and Preece TF (Eds). Microbiology of Aerial Plant Surface. Academic Press, London

Stanbury P, Whitaker A, Hall S (2016) Principles of Fermentation Technology. Third Edition. Butterworth Heinemann, Oxford

Widanengsih E (2015) Jenis-jenis hama dan penyakit pada tanaman kelapa sawit. Stasiun Karantina Pertanain Kelas II Tanjung Balai Karimun. http://skpkarimun.or.id. Diakses 15 November 2015 